\title{
Pan American Exhibit
}

As a result of an invitation from the Pan American Union of Washington, D. C., to participate in the commemoration of Pan American Day on April I4, the Baker Library has installed a special exhibit of materials on the industry and commerce of all Central and South American countries. According to present plans the exhibit will be retained until the middle of May. The Business Historical Society has played an active part in securing the material for this display.

Action photographs of processes in the industries of the various countries, advertising material, and samples of products compose the exhibit. In collecting the various parts of the display, the Library had been aided by the general consuls of the South and Central American countries in Washington and by corporations whose trade activities bring them into contact with Central and South America.

Preparation for the exhibit has been a collaborative effort on the part of Professors J. Anton de Haas and George B. Roorbach of the Harvard Business School and Mr. Frank C. Ayres, Executive Secretary of the Society.

\section{War as a Stimulus to American Industry}

IN THE history of America, war has proved a powerful stimulus to industry. Naturally, hostilities will bring forth increased activity in most branches of trade, which enhancement of activity lasts only during the persistence of the war stimulus. However, there have been a few industries in each major war that have been permanently advanced. A survey of the diversified collections in the Society's possession calls to mind certain industries that normal development would have caused to bloom at a much later date and others that might never have been developed had it not been for the exciting influence of war.

Before the War of 1812, the cotton-goods industry had been operated on a small scale basis. Individual companies were run with limited capital by a group of men lacking vision. With the destruction of foreign commerce coincident with the War, America became dependent on herself for her cotton-goods supply. Prices of cotton-goods soared in sympathy with the rise of general com- 